\title{
A Critical Reflection of Service Learning: A Higher Education Perspective
}

\author{
S. Ramsaroop \\ University of Johannesburg \\ saritaram@uj.ac.za \\ J. Ramdhani \\ University of KwaZulu Natal \\ Ramdhanij@ukzn.ac.za
}

\section{Doi:10.5901/mjss.2014.v5n20p1331}

\begin{abstract}
This article draws on the reflections of the pedagogical practice of service learning in higher education. Mahlomaholo (2010) described crisply the "context of educational dysfunctionality suffusing the country". The question often pondered about is: what skill and knowledge can be infused to make teaching at higher education institutions, to reflect the realities of society. Using critical reflection we asked: "[i]s your teaching worthy?"). The business management methods module allows for the pedagogical practice of service learning to be incorporated into the assessment. By adopting a constructivist approach to teaching business management method content means that the business management instructor is building on students' previous knowledge and allows the students to draw from their own experiences, thereby providing a scaffold for the students to develop an increased understanding of the business management pedagogical issues being discussed. As a business management method instructor choosing a pedagogical approach, that can address categories of significant learning, is an important step in developing learning that is durable. There are many views about how constructivist approaches to learning can or should, be aligned to constructivist approaches to teaching. The two pedagogical practices that can be effectively incorporated in business management education are: cooperative learning and service-learning. This paper uses auto ethnography to focus on the instructor's subjective experience of using service learning as a pedagogical approach.
\end{abstract}

Keywords: Service Learning; Community; Pedagogy; Critical Reflection; Business management

\section{Introduction}

Brookfield (1995, p.46-7) proposes that tracking the "worth of your teaching is through the process of critical reflection [especially within emerging countries]." Given that South Africa as a country has many challenges, one of which is the vulnerability of its communities. Some of the issues that the communities have to deal with include, poverty, lack of service delivery, housing shortages, poor sanitation, issues of unemployment, diseases such as HIVIAIDS, tuberculosis and malaria, and environmental degradation such as overgrazing, droughts and floods. Uys (2005) argues that for the advocates of critical curriculum theory the purpose of education is to enable students "to become transformers of society" and thereby enabling students to think critically, to make decisions and take actions which will improve the society in which they live. The outcomes of a study conducted by Ramdhani and Ramsaroop (2012) emphasise the need for teachers to also reflect continuously on their practice and on their role in allowing students to become transformers of society through the use of teaching strategies that will facilitate aesthetic understanding and experiences of the content taught. Le Grange (2007) indicates that just educating students about the challenges that communities face sends the message that it is fine to just learn about these issues without having to do anything to help address this issue. It is within this context that community service learning or service learning comes into play. Community service-learning has made a recent appearance in South Africa. Its emergence in higher education (HE) curricular can be attributed to the policies of the Department of Education (DOE) in the late 1990's. Interest in community service-learning is growing in South Africa, ostensibly because it opens up opportunities for contributing to the transformation of higher education as higher education institutions (HEIs) "are urged to become more democratic, more responsive to community challenges, and conducive to partnership-building with a variety of stakeholders" (Erasmus, 2007:1).

Those who argue for the incorporation of social justice in the curriculum are of the view that including issues of social justice stimulate educational and socio-economic equity for all students in higher education. We draw on the views of Petersen (2008) who argue that "social justice includes the full and equal participation of all groups in a society that is 
mutually shaped to meet their needs. Social justice includes a vision of society in which the distribution of resources is equitable and all members of physically and psychologically safe and secure ... social justice involves social actors who have a sense of their own agency as well as a sense of social responsibility toward and with others and the society as a whole." Social justice stresses that people be given equal rights and opportunities. This includes everyone, from the marginalized to the wealthiest have earned the right to have an even playing field. So the question of how practical and sustainable it is for the lecturer to incorporate issues of social justice using service learning within the individual disciplines of teacher education curriculum? This qualitative research drew on auto ethnography as a methodological tool of critical reflection in search of portraying and understanding the process of meaning making in the incorporation of service learning as a pedagogical tool, from a lecturer's perspective. Therefore, this paper explores closely the reflections of a lecturer's subjective experience of service learning in a business management method module at a higher education institution. At this point, it becomes necessary for us to explore the literature that exists on service learning

\section{Literature Review}

The following paragraph/s will highlight past and present research on service learning. At this junction it is important to clarify the term service learning (SL).A clarification of the term is important as it creates a foundation on which to build an argument around which service learning will be can be theorized. Various definitions of service learning exist and in some of the literature service learning is referred to as community service learning. This paper would use the term service learning (SL) as used by (Marullo \& Edwards, 2000) as it best describes the activities of the students in this endeavour. Marullo \& Edwards (2000) make a key distinction between service-learning based on charity and service-learning based on social justice in that the service undertaken by the students is based on social justice, and their engagement in this academic experience moves beyond simply reflecting on their experiences of volunteering time to work with less privileged members of the community and gaining course credits towards understanding deeper systemic issues of power and inequality.

We draw on Wong (2008) who contended that "powerful, experiential learning events can provide preservice teachers with the opportunity to learn about diversity and challenge their preconceived ideas about various cultural issues". Pre-service teachers involved in the project mature in the following manner: transactional relationships (impersonal), transformational relationships (curiosity about tutees backgrounds) and trancedent relationships (acknowledging significant personal growth in personal ideas and beliefs and recognize how institutional and social structures impact on minority students in negative ways) with their tutees. Diambra, McClam, Fuss and Fudge (2009) observed that apart from providing an atmosphere that can be therapeutic, focus groups in service-learning helps students clarify their roles and provides opportunities for revealing student anxieties. We use Wong (2008) and Diambra, McClam, Fuss and Fudge (2009) to explore the trancedent thinking from a lecturer's perspective.

The need to address the challenges in South Africa, and especially at the Children's Homes/ Orphanage through service learning created a movement from charity to service learning based on social justice in business management method education. Although Furco $(2002$, p.5) reminds us that in service learning there has to be service and the learning automatically follows. The service learning program is not intended to be essentially an experiential education approach in which students receive academic credit for performing community service (Osman, 2007, p.15) but social justice and social injustice issues forms a large part of the process of student learning (especially in learning from experience as Noddings (1984, p.173) indicated. Butin (2003, p.1675) on the other hand, had a different view and envisaged service learning "could serve a powerful counterpoint to positivist educational trends that de-professionalise teaching through prescriptive curricula, behaviourist outcomes and instrumental views of teaching and learning. Furthermore, terms such as service-learning also have great appeal as political slogans, because they embrace what appear to be disparate aspirations.

Some of the debate that surrounds SL focuses on its nature (what it is). For example, is it pedagogy, a philosophy or a form of inquiry (a methodology)? Or does it encompass all of these? (Le Grange, 2007, p.40). SL is not a new concept if one considers the views projected by Dewey (1939) that "students tend to learn the course content associated with a service-oriented activity when they make a connection with its cause" (Jensen, 2006, p.1). The formal definition and labelling of the term service learning took root in the mid 1980's.

However Jensen (2006) maintained that the terms service learning is not synonyms with service. If a learning activity is to be classified as service learning, it must be linked to a learning goal or objective that forms part of the curriculum. The National and Community Service Trust Act of 1993, defines SL as a teaching strategy whereby students learn and develop while actively engaging in a thoughtfully organized service.

Dewey's advocated for experiential learning which entails a process of interaction between the student and his 
environment. Much literature has been documented about the merits of service learning as a pedagogic strategy that contributes to cognitive development (Jones and Abes 2004; Billig and Klute, 2003). Service learning as pedagogy is seen as a form of experiential education that involves reflection as a means of control that learning has occurred. Experiential learning (EL) is a process whereby students reflect on their "experience by identifying what happened" (Mc Millian, 2000, p.3). Jensen (2006, p.2) argues that the benefits of engaging students in a SL activity can assist students to retain the course material for longer periods of time because the students begin to see the relevance of their learning as it pertains to everyday life experiences and issues. This fact was established by Brophy (1986) that teachers endorse that fact that learning environments that foster academic achievement through hands-on, authentic learning inspire students by involving them in their own learning process.

In building an understanding of the theory that surrounds service learning in the community, it would be necessary to gain a clear understanding of the term community. For the purposes of this study the community will refer to as any social, geographical or interest group, in which the diversity of the group members leads to the development of complex interactions, relationships and processes. As a researcher we are mindful that the term community has both a positive and negative connotation. Positive as social groups to which people belong, or to those to which one assumes others belong. Pillay (2008) further, reminds us that "community" was confused with legislated racial categories during the apartheid era.

Mahlomaholo and Matobako (2006) argue that there are three levels in which service learning in the community can be theorized, namely, as charity, as project and genuine committed engage. Not much engagement takes place with the community at the charity level and the most power lies with the institution of higher education. Here it is a looking down upon the poor community and the university as being the most knowledgeable. The project level is a sort a midway between the charity level and where service learning takes place at a genuine level with the community. More preparation takes place at this level there both the lecturer and student may really and honestly want to operate on an equal level with the community. The intention is to better the lives of communities, thereby seeing the community as an outside agency and so service learning is doing for the community and working with the community. We see the service learning in economic education to be positioned more as a genuine engagement and this requires exceptionally high quality and a very intensive critical introspection. Therefore, build into the service learning is a truly shared endeavour, or reciprocity.

Le Grange (2007) has indicated that as a relatively new education phenomenon community service- learning has been subjected to numerous criticisms. One of the criticisms stems from the fact that the theoretical foundation that underpins service learning is very thin. Osman (2007) drew our attention to community service learning by accepting the community service learning initiatives within higher education but argues that one must take cognizance of the ways in which power relations might be concealed within the community service learning initiatives within higher education. By contrast Daniels (2007) argues for critical citizenship advancement through community service learning for Adult Basic education and training (ABET). Berman (2007) shows that there is incompatibility between community engagement and the research culture that exist at Institutions. However it must be pointed out that Mitchell and Humphries (2007) argued that service learning is becoming a widespread phenomenon and there is in "danger of becoming a technical practice with a "charity" orientated form of engagement with communities".

Bringle and Hatcher (2007) focus on ways in which service learning and civic engagement are shaped by context and "in what ways do these two trends contribute to higher education's trajectory for an appropriate future as a mature, responsible, and responsive institution with society." This research focused on the implications of civic engagement and service learning for higher education in America and South Africa. Lazarus (2007) followed up on the developments of Community- Higher Education-Service Partnership (CHESP) initiative and its contribution towards entrenching service learning within Higher Education in South Africa. Whilst, Bender et al (2007, p.127) argued that without a fully conceptualised notion of how the external, internal and personal segments of educational change interlink, "the existing educational change for CCE and specifically CSL, will remain underdeveloped and of progressively less use at HEI s in South Africa." The abbreviations CCE refer to Curricular Community Engagement, CSL to Community Service Learning and HEI to Higher Education Institution. Erasmus (2007) focused on community engagement (and service learning in particular) and the reality in terms of academic staff members perceptions of the lack of substantial support for their efforts in implementing community service learning. An exemplar on how to incorporate service learning as a case study was provided by Bheekie, Adonis and Daniels (2007) with particular reference to undergraduate training in pharmacotherapy service-learning. Petersen (2007) also provides an insight in the pre-service student's engagement with service learning with particular reference to care and social justice.

The belief was that the ways in which community knowledge and skills are acknowledged or not taken into account in the curriculum could enhance the economic education program immensely (Alperstein, 2007). This importance of the community in service learning in higher education, particularly with regard to community perspective on community 
needs, service learning benefits, student's performance and areas in which service learning can be improved has been researched by Nduna (2007) and Rensburg (2007) reiterated this when he looked at student learning in Community Service Learning in a Language Teaching programme.

\section{Research Methodology}

This qualitative paper drew on auto ethnography as a means of searching, portraying and understanding the process of meaning making of the service learning in business management method program. Silverman (2001, p.25) argued that qualitative research covers a wide range of different, even conflicting, activities. Qualitative research seems to promise that we will avoid or downplay statistical techniques and the mechanics of the kinds of quantitative methods used in, say, survey research or epidemiology. The danger in the term, however, is that it seems to assume a fixed preference or predefined evaluation of what is "good" (i.e. qualitative) and "bad" (i.e. quantitative) research. In fact, the choice between different research methods should depend on what one is trying to find out. As a researcher, adopting a qualitative method of research will provide a deeper understanding of social phenomena of critical reflection of service learning as a tool in business management education than would be obtained if we had used a purely quantitative data. As the purpose of this paper was to explore closely the reflections of a lecturer's subjective experience of service learning in a business management method module at a higher education institution, research relied on the 'analysis of words and images rather than numbers' (Opie, 2004, p.74). As a researcher the study is concerned to explore an in-depth understanding of certain behaviours, specifically lecturer's subjective experience of service learning. A qualitative method feeds in brilliantly as it is an open-ended approach which allows for an exploration of interesting data through which to interpret and find answers to provide the rich information required. We adopted a qualitative research method because we were striving to achieve depth of understanding rather than "quantity of understanding" (Henning, Van Rensburg and Smit, 2004, p.3). This paper relied on the self-reflection of the lecturer to explore the personal experience and to make the connection to the wider cultural, political and social meanings. Brookfield (1995, p46-7) argues that by sharpening their personalised "authentic voice" and "a pedagogical rectitude" assists the teacher/ lecturer to expose the "value and dignity" of their teaching "because now we know that its worth." We could have used any one of Brookfield's (1995, p46-7) suggestion for critical reflection which involved the following: "autobiographical", "the students eye", "our colleagues' experiences" and "theoretical literature". As researchers as we outline the personal thoughts, feelings, stories and observations of the lecturer (one of the researchers in this paper) and this allowed for the reader to feel the lecturers' full engagement with the process of service learning. However, in this instance, auto ethnography was most suitable as qualitative research method as it allowed us to focus on the lecturer's subjective experience of service learning as a pedagogical tool, rather than relying on ethnography which relies on the beliefs and practices of others. As early as 1983, Schon contended that "a competent reflective practitioner repeatedly reflects on experience and is capable of reflecting in action, continually learning from experience to the benefit of future action."

\subsection{Findings and Discussion}

The following paragraphs will provide a discussion of the auto ethnographic account of service learning in the module. The section is divided into two sub-categories, namely: the journey and the process of service learning in business management method.

\subsection{The journey}

Let us begin with where the roots of service learning began for this lecturer. The journey into service learning began as early back in the lecturer's personal life when as a child; her father got the entire family, mother and children, to be involved in catering for the needs of people, through a soup kitchen. This involvement in the soup kitchen was a form of service or charity and made the lecturer ask later on: how can service to mankind be incorporated into the curriculum? This question and the following extract from the reflection in italics is in keeping with the definition proposed by Marullo \& Edwards (2000) on key distinction between service-learning based on charity and service-learning based on social justice.

So this question took the on a new route in my journey and led to the days of working with street children, an avenue that was selected as part of an assessment in the psychological perspectives module in the $B$. Ed Honours program. The lecturer then undertook to provide the children at the Children's home with an entrepreneurial skill that would equip them to become entrepreneurs when they are required to leave the Children's Home at the age of 18. This 
was service learning in psychological perspectives module. The journey goes further, still, when as a commerce lecturer in the Faculty of Education at a higher education institution, a pilot project was undertaken in the business management module, whereby students or pre-service teachers (used interchangeably) worked with disadvantaged children in orphanages to equip them with skills in drawing up a business plan, a skill that could prove handy when required to provide for themselves due to age, as clearly outlined by Maistry \& Ramdhani (2010). This is a further example of service learning in business management. This journey continued in 2010 where a further question exploration into service learning was attempted in another higher education institution in subject methodologies of both economics and business studies with students registered for post graduate certificate in education (PGCE). The journey reached a pinnacle in 2013 when service learning was reintroduced in the current higher education institution under the module of business management method.

\subsection{The process of service learning in business management method}

As a lecturer of business management methodology one often reflects by drawing on O Donnell $(2001, p .1)$ on what is it students should know and be able to do after they leave the university. Preparing students to participate in society and in particular the economy is important but the challenge comes in that what skills and knowledge should the module draw on to make this a reality. By incorporating approaches that draws on constructivism to teach business management methodology requires the students to build on their previous knowledge and to draw from their own experiences, thereby providing a scaffold for the students to develop an increased understanding of the what, how and why of business management methodology being discussed. This is reflected in what Osman $(2007, p .15)$ reasoned that service learning program is more than obtaining credits but rather an involved introspection of social in/justice that pervades society. How then, can business management methodology adopt the pluralistic perspective (Petersen, 2009)? Choosing a pedagogical approach that allows for critical reflection and can address categories of substantial learning is vital in nurturing learning that is durable.

This means that from a pluralistic perspective, exposing the students to multiple paradigms creates a foundation for debates on appropriate content coverage. We agree that content and pedagogy is interrelated and that a change in the pedagogy will provide a strong foundation to achieve the necessary content transformation if pluralism is the way to go. In addition learning theory is fundamental to developing this foundation. The pluralism perspective if founded on the statement that if the intention of business education is to get students to have a better understanding of how the world works and for them to be active citizens of this democracy, then it should follow that economic education should emulate the world and allow for participation. This participation can only take place by making the classroom to be very inclusive by changing learning from being individualistic to becoming group learning and eventually to grow to become learning communities. This means thinking outside of the orthodox business management methodology. Dorman (2002, p.489-90) pointed out that the classroom is a social setting and learning is enhanced when ideas are shared and challenged.

Working in groups helps learners to construct their own understanding and learn more effectively. Students learn from their experiences with each other and critical thinking involves challenging of perspectives and developing students' problem-solving skills. Barone (1991, p.18) suggested that by challenging perspectives students are exposed to a wider range of economic phenomena and the human values underlying economic actions. This capacitates student with the skills to evaluate and assess policy choices. Knoedler and Underwood (2003) indicated that the multi-paradigm approach creates an avenue for students to understand the way the economy works. By adopting a constructivist approach to teach economic content means that the business studies instructor is building on students' previous knowledge and allows the students to draw from their own experiences, thereby providing a scaffold for the students to develop an increased understanding of the economic issues being discussed. This, according to Fuss and Fudge (2009), can look at their responsibility but also create a platform for them to express their angst.

The module under discussion was located at the higher education institution under the B.Ed. qualification. So how did the business management method module (from here on will referred to as the module) in education adopt the pluralistic perspective? As the module instructor choosing a pedagogical approach that can address categories of significant learning is an important step in developing learning that is durable. There are many views about how constructivist approaches to learning can or should, be aligned to constructivist approaches to teaching. However, there is tremendous support for the philosophy that constructivist teaching 'is based on the generalised belief that learners' develop understanding when they are active and seek solutions for themselves' (Killen, 2000). The two pedagogical practices that can be effectively incorporated in economic education are: cooperative learning and service-learning. The pedagogical route that the pre-service students in the module travelled was one of service learning. Service learning was reintroduced as part of a pedagogical tool but the difference was that students now had to select their own Orphanages 
or Children's home to work with. By linking the curriculum to the community needs, the lecturer was creating an environment for learning to be classified to service learning (Jensen, 2006)

In the previous reporting by Maistry and Ramdhani (2010) the introduction of service learning as pedagogy relied on the NGO to allocate students to the Orphanages or Children's Homes. The module focuses on three questions: namely, what, how and why? What referring to the content relevant to the business management for further education and training level. How referring to the approaches and methods of teaching, including the development of writing and critical thinking skills through their service learning engagement. Why referring to the philosophy and theories that underpin the content and the approaches and the methods. The assessment for required students to work closely with an Orphanage or Children's home (will be referred to as Home from here onwards). After doing an assessment of the home and liaising with the children and the administrators, the student had to draw up a business plan for the Home. A subsection of the assessment required the students to do a reflection on the three aspects: first, their experiences of working with a Home. Second, their joys and challenges of drawing up a business plan for the Home and third, their views on the incorporation of service learning as pedagogical tool at higher education and in schools. A space is created during lecture time for students to discuss their reflections.

We drew and adapted Wong (2008) vision of transcendent relationships to illustrate in the following paragraphs the personal growth in the lecturer and how society's institutions have an impact on students and how this was reflected by the lecturer. This is captured in the followed words from the lecturer reflection below:

\begin{abstract}
As a lecturer, I could feel the anxiety and awe-inspiring experience that was being shared by the few students who volunteered to reflect at the plenary. It was at this juncture that I felt that a bombshell had dropped as one student stood and explained his journey while doing the assessment. I heard the disquiet and nervousness in his voice as he explained that he wondered why such an assessment was given, because he had been brought up in an orphanage himself and was later fostered by a family. I could feel the goose bumps as he explained that he chose the orphanage that we was in as a child and his angst to actually enter the gate of the premises. It was difficult to not feel the unease within myself as he recounted going four times to the gate before actually entering. As if that was not enough, as lecturer you start to ask yourself: what such an assessment did to the student, despite having the student profiles done at the beginning of the semester. The anxiety was real as I and the group mentally walked through the orphanage with him and sat on the chair in front of the administrator. I felt his comfort as the administrator (same as before) took him to his cottage and he spoke to the current inhabitant of his previous bed. My feelings of sadness and revelation were all trapped inside of my professionalism, as he was told the reasons for him being put in the home.
\end{abstract}

\title{
4. Conclusion
}

In concluding this paper we believe that by looking at the transcend thinking and the self-reflection of pedagogues is valuable for lecturers to consider what is the paradigm shift that takes place within when deciding on adopting service learning for sustainable developments of education and the community.

\section{References}

Alperstein, M. (2007). Getting closer to the Community Voice in Curriculum Development: an Exploration of the Possibilities. Education as change. Special issue: Community Service Learning, 11(3), 59-67.

Barone, C.A. (1991). Contending Perspectives: Curricular Reform in Economics" Journal of Economic Education, Vol. 22(1):15-26.

Bender, C.J.G., Daniels, P., Lazarus, J., Naude, L. \& Sattar, K. (2007). Service-Learning in the Curriculum. A Resource for Higher Education Institution. Jet Education Services. Pretoria.

Berman, K. (2007). A case study of Phumani Paper as a Community Engagement initiative at the University of Johannesburg. Education as change. Special issue: Community Service Learning, 11(3), 37-45.

Bheekie, A., Adonis, T. \& Daniels, P. (2007). Contextualizing undergraduate training in service-learning at the University of Western Cape. Education as change. Special issue: Community Service Learning, 11(3), 157 - 167.

Bringle, R.G. \& Hatcher, J. A. (2007) Civic Engagement and Service Learning: Implications for Higher

Brookfields, S. (1995). Becoming a Critical Reflective Teacher, San-Francisco: Jossey Bass

Butin, D.W. (2003). "Of What Use Is It? Multiple Conceptualizations of Service-Learning in Education", Teachers College, Columbia University

Daniels, D. (2007). Advancing critical thinking about adult basic education through academic service learning.

Diambara, J.F., McClam, T., Fuss, A, Burton, B., Fudge, D.L. (2009). Using a focus group to analyse students' perceptions of a servicelearning project, College Student Journal, 43(1), 114-122.

Erasmus, M. (2007). Supporting academic staff as champions of service learning. Education as change. Special issue: Community Service Learning, 11(3), 109-126. 
Furco, A. \& Billing, S. H. Jr. (1999). Where's the Learning in Service Learning. San Francisco: Jossey Bass Publishers.

Henning, E., Van Rensburg, W. \&Smit, B. (2009). Finding your way in qualitative research. Pretoria: Van Schaik Publishers.

Jensen, S.V. (2006). Participation and Learning Relationships: A Service-Learning Case Study. Journal of Industrial Teacher Education [online], 43(3): 1-14. Available: http://scholar.lib.vt.edu/ejournals/JITE/v43n3/jensen.html, [Accessed1 June 2009].

Jones, S.R. \& Abes, E.S. (2004). Enduring influences on service learning on college students' identity development. Journal of College Student Development, 45, 149-166.

Lazarus, J. (2007). Embedding Service Learning in South African Higher Education: The Catalytic Role of the CHESP Initiative. Education as change. Special issue: Community Service Learning, 11(3), 91-108.

Le Grange, L. (2007). The "theoretical foundations" of community service-learning from taproots to rhizomes. Education as change. Special issue: Community Service Learning, 11(3), 3-13.

Mahlomaholo, S. \& Matobako, T. (2006) Service Learning in South Africa Held Terminally Captive by Legacies of the Past. Alternation Journal 13). UKZN

Maistry, S.M. \& Ramdhani, J. (2010). Managing tensions in a service-learning programme: some reflections. South African Journal of Higher Education, 24(4).

Maréchal, G. (2010). Auto ethnography. In A. J. Mills, G. Durepos \& E. Wiebe (Eds.), Encyclopedia of case study research (Vol. 2, pp. 43-45). Thousand Oaks, CA: Sage Publications.

Marullo, S. \& Edwards, B. (2000). From charity to justice: the potential of university-community collaboration for social change, American Behavioural Scientist, 43, 895-912.

McMillian, J. (2000). Service-Learning as experiential learning: Brining Community into Higher Education: Paper presented at CHED. Advanced Research Seminar.

Merriam, S. B. (1998). Qualitative Research and Case study Applications in Education: San Francisco: Jossey Bass Publishers.

Mitchell, C \& Humphries, H. (2007). From notions of charity to social justice in service-learning: The complex experience of communities. Education as change. Special issue: Community Service Learning, 11(3), 47-58.

Nduna, N.J. (2007). The community voice on service-learning: A good practice guide for higher education. Education as change. Special issue: Community Service Learning, 11(3), 69-78.

Noddings, N (1984) Caring: A Feminine approach to ethics and moral education, University of California Press, London.

O'Donnell, R. (2002). "What Kind of Economics Graduates Do We Want? A Constructive Critique of Hansen's Proficiencies Approach". Working Paper No 203. Macquarie University, Department of Economics. Available from http://www.econ.mq.edu.au/research /2002/3-2002_ODonnell.pdf (Accessed 16 April 2010).

Osman, R \& Attwood, G. (2007). Power and participation in and through service-learning. Education as change. Special issue: Community Service Learning, 11(3), 15-21.

Petersen, J \& McGoldrick, K (2009). Pluralism and Economic Education: a Learning Theory Approach. Journal: International Review of Economics Education, 8(2):72-90. Available from: http://ideas.repec.org/a/che/ireepp/v8y2009:2p72-90.html. (Accessed 15 April 2010).

Petersen, N., Dunbar-Kriger, H. \& Fritz, E. (2008). Chronicling a Faculty of Education's journey into community engagement through service learning. Education as Change, Vol.12

Pillay, J. (2007). Constructing Community Educational Psychology in South African Higher Education Institutions. Inaugural Lecture Department of Psychology, University of Johannesburg, June 2007.

Ramdhani, J. \& Ramsaroop, S., 2012, 'Moving sciences beyond museums and theatres', Koers - Bulletin for Christian Scholarship 77(1), Art. \#32, 6 pages. http:// dx.doi.org/10.4102/koers. v77i1.32

Schon, D.A. (1983). The Reflective Practitioner: How Professionals think in Action. New York: Basic Books

Silverman, D. (2000). Doing Qualitative Research: A Practical Handbook. London. Sage.

Uys, L. R. \& Gwele, N.S. (2005). Curriculum development in nursing: process and innovations. Milton Park, Abingdon: Routledge.

Van Rensburg, W. (2007). CSL, Multiliteracies and Multimodalities. Education as change. Special issue: Community Service Learning, 11(3), 191-192.

Wong, P. (2008). Transactions, Transformations and Transcendence; Multi-cultural service-learning experience of pre-service teachers. Multicultural Education. 16(2). 31-36. 